\title{
PEMANFAATAN PELEPAH DAUN KELAPA SAWIT FERMENTASI DENGAN Aspergilus niger TERHADAP PERFORMANS SAPI BALI JANTAN
}

\author{
(Utilization of Oil Palm Frond Fermented by Aspergilus niger on \\ Performances of Bali Cattle Males)
}

\author{
Musa Seno Ibrahim ${ }^{1}$, Usman Budi² dan Tri Hesti Wahyuni \\ 1. Mahasiswa Program Studi Peternakan Fakultas Pertanian Universitas Sumatera Utara \\ 2. Staf Pengajar Program Studi Peternakan Fakultas Pertanian Universitas Sumatera Utara
}

\begin{abstract}
Giving oil palm frond fermentation in the feed gives the economic value and increase profits weaning male bali cattle. This study conducted in Dusun 1 (Sembat) Nagori Marihat District Line Dolok Marlawan Simalungun. This reserach held for three months starting in January 2013 until May 2013. This study used 12 male Bali cattle with a randomized block design as experimental design, consisting of 4 groups such as distinguished based on male bali cattle body weight. With initial body weight: $(R 1=102,33 \mathrm{~kg} \pm 9,29 ; R 2=121,00 \mathrm{~kg} \pm$ 6,56; $R 3=140,67 \mathrm{~kg} \pm 5,03$; dan $R 4=162,67 \mathrm{~kg} \pm 7,51)$. There are three treatments such as: $P 0(25 \%$ fresh oil palm frond), P1 (20\% oil palm frond fermented) and P2 (30\% oil palm frond fermented). The results showed that the utilization of oil palm frond with fermented Aspergillus niger on Males Bali Cattle Peformances on feed intake ( $\mathrm{g} /$ head / day) for treatment P0; P1; P2 were 5.62; 5.94; and 5.64, respectively. Average daily gain (ADG) ( $g$ / head / day) for treatment P0; P1; P2 were 0.46, 0.65 and 0.53, respectively, while for feed conversion ratio were 12.19; 9.46 and 10.25, respectively. Statistical test showed that oil palm frond fermented significantly different $(P<0.05)$ effect on feed intake, average daily gain and decrease feed conversion ratio on male bali cattle. The conclusion of this research is that oil palm frond fermented with Aspergillus niger can be increase feed intake, average daily gain $(A D G)$ and decrease feed conversion rate.

Keywords: oil palm frond, Fermentation, Aspergillus niger, Performances, Male Bali Cattle
\end{abstract}

\begin{abstract}
ABSTRAK
Pemberian pelepah daun kelapa sawit fermentasi dalam pakan memberi nilai ekonomis dan meningkatkan keuntungan penggemukan sapi bali jantan lepas sapih. Penelitian ini dilaksanakan di Dusun 1 (Sembat) Nagori Marihat Baris Kecamatan Dolok Marlawan Kabupaten Simalungun. Penelitian ini telah dilaksanakan selama tiga bulan yang dimulai pada bulan Januari 2013 sampai Mei 2013. Penelitian ini menggunakan 12 ekor sapi bali jantan dengan rancangan acak kelompok, terdiri atas 4 kelompok yang dibedakan berdasarkan bobot badan sapi $(\mathrm{R} 1=102,33 \mathrm{~kg} \pm 9,29 ; \mathrm{R} 2=121,00 \mathrm{~kg} \pm 6,56 ; \mathrm{R} 3=140,67 \mathrm{~kg} \pm$ 5,03; dan R4 = 162,67 kg $\pm 7,51$ ). Ada tiga perlakuan yaitu P0 (ransum dengan 25\% pelepah daun kelapa sawit segar), P1 (ransum dengan 20\% pelepah daun kelapa sawit fermentasi) dan P2 (ransum dengan 30\% pelepah daun kelapa sawit fermentasi). Hasil penelitian menunjukkan bahwa Pemanfaatan Pelepah Daun Kelapa Sawit yang difermentasi Aspergillus niger terhadap Performans Sapi Bali Jantan terhadap konsumsi pakan (kg/ekor/hari) 5,62; 5,94; dan 5,64. Rataan pertambahan bobot badan (g/ekor/hari) 0,46; 0,65 dan 0,53. Konversi pakan 12,19; 9,46 dan 10,25. Uji statistik menunjukkan bahwa pelepah daun kelapa sawit fermentasi berbeda nyata $(\mathrm{P}<0.05)$ terhadap konsumsi pakan, pertambahan bobot badan dan menurunkan konversi pakan sapi bali jantan. Kesimpulan hasil penelitian ini menunjukkan bahwa fermentasi pelepah daun kelapa sawit dengan menggunakan Asprgillus niger dapat meningkatkan konsumsi dan pertambahan bobot badan serta menurunkan konversi pakan sapi bali dibandingkan dengan pelepah kelapa sawit segar.
\end{abstract}

Kata Kunci: Pelepah daun kelapa sawit, Fermentasi, Aspergillus niger, Performans, sapi bali jantan 


\section{PENDAHULUAN}

Ternak potong di Indonesia memiliki arti yang sangat penting, terutama dikaitkan fungsinya sebagai penghasil daging, tenaga kerja, penghasil pupuk kandang, tabungan, atau sumber rekreasi. Arti yang lebih utama adalah sebagai komoditas sumber pangan hewani yang bertujuan untuk kesejahteraan manusia, memenuhi kebutuhan selera konsumen dalam rangka meningkatkan kualitas hidup, dan mencerdaskan masyarakat. Perkembangan arus permintaan yang semakin pesat terhadap produk peternakan ini, tentu saja harus diimbangi dengan upaya melakukan penerapan teknologi yang semakin meningkat pula. Tujuannya adalah agar tercapainya produksi yang maksimal, sehingga pemenuhan kebutuhan protein hewani dapat terpenuhi dan dapat menciptakan sumber daya manusia yang produktif dan unggul.

Perkembangan penerapan teknologi terhadap produksi peternakan diawali dengan membentuk suatu manajemen yang terorganisir dari segala aspek yang diperlukan, baik itu manajemen waktu, manajemen pemeliharaan dan manajemen pakan. Diketahui bahwa pakan merupakan salah satu faktor penting dalam menghasilkan produksi yang tinggi. Efesiensi penggunaan pakan dapat dicapai secara maksimal apabila bahan pakan lokal terutama pemanfaatan bahan pakan ternak asal limbah pertanian dan limbah perkebunan dapat termanfaatkan secara optimal.

Salah satu contoh hasil samping perkebunan di provinsi Sumatera Utara yang memiliki potensi yang sangat besar dijadikan sebagai pakan ternak yaitu perkebunan kelapa sawit. Bila mengikuti sejara perkembangan perkebunan kelapa sawit di Provinsi Sumatera Utara sendiri, mulai tahun 2005 luas perkebunan kelapa sawit mencapai 948.800 Ha dengan produksi tandan buah segar sebanyak 3.439.748 ton sehingga di wilayah Sumatera Utara tingkat pertumbuhan produksi perkebunan kelapa sawit sangat signifikan dalam menghasilkan banyak hasil samping. Hal ini memberikan peluang bagi peternak dalam memanfaatkan hasil samping dari perkebunan kelapa sawit sebagai pakan alternatif ternak (khususnya ternak sapi).

Hasil samping perkebunan kelapa sawit yang paling utama dapat dimanfaatkan sebagai pakan ternak ruminansia yaitu pelepah daun kelapa sawit. Pelapah daun kelapa sawit dapat diperoleh sepanjang tahun bersamaan panen tandan buah segar. Pelepah daun kelapa sawit dipanen 1-2 pelepah/panen/pohon. Setiap tahun dapat menghasilkan 22-26 pelepah/ pohon dengan rataan berat pelepah daun sawit 4-6 kg/pelepah, bahkan produksi pelepah 
dapat mencapai 40-50 pelepah/pohon/tahun dengan berat sebesar 4,5 kg/ pelepah (Umiyasih et al., 2002).

Pelepah daun kelapa sawit memiliki potensi yang besar untuk dijadikan salah satu pakan alternatif. Namun tingginya kandungan serat kasar yang terkandung pada pelepah daun kelapa sawit menyebabkan rendahnya tingkat kecernaan. Penggunaan Aspergillus niger dalam proses fermentasi diharapkan mampu meningkatkan kecernaan pelepah daun kelapa sawit.

Mengacu pada hal tersebut penulis tertarik untuk meneliti lebih lanjut seberapa tinggi tingkat pemberian hasil samping kelapa sawit pada sapi Bali yang dapat memberikan konsumsi, konversi dan pertambahan bobot badan yang optimal.

\section{BAHAN DAN METODE}

\section{Lokasi dan Waktu Penelitian}

Penelitian ini dilaksanakan di Dusun 1 (Sembat) Nagori Marihat Baris Kecamatan Dolok Marlawan Kabupaten Simalungun. Penelitian ini telah dilaksanakan selama tiga bulan yang dimulai pada bulan Januari 2013 sampai Mei 2013.

\section{Bahan dan Alat Penelitian}

Bahan yang digunakan dalam penelitian ini adalah 12 ekor sapi bali jantan lepas sapih, pakan yang terdiri atas: pelepah daun kelapa sawit fermentasi, bungkil inti sawit, lumpur sawit, dedak padi, onggok, molasses, urea, garam dan ultra mineral, obat-obatan dan air minum.

Alat yang digunakan dalam penelitian ini adalah kandang individual sebanyak 12 unit $(1,5 \mathrm{~m} \times 2 \mathrm{~m})$ beserta perlengkapannya, tempat pakan dan minum, timbangan untuk menimbang berat badan sapi selama penelitian, timbangan dengan kapasitas $1000 \mathrm{~kg}$ dengan kepekaan $1 \mathrm{~kg}$ untuk menimbang konsentrat, kandang jepit yang digunakan pada saat penimbangan bobot badan sapi dilaksanakan, alat kebersihan (ember, sapu, angkong, sabit, tempat sampah), lampu sebagai alat penerangan, kalkulator sebagai alat untuk mempermudah perhitungan, dan alat tulis sebagai alat pencatat data selama penelitian.

\section{Metode Penelitian}

Metode penelitian yang digunakan adalah rancangan acak kelompok (RAK) dengan 3 perlakuan dan 4 kelompok. Perlakuan yang akan diteliti sebagai berikut : 
$\mathrm{P}_{0}=$ Pakan dengan 25\% Pelepah Daun Kelapa Sawit Segar

$\mathrm{P}_{1}=$ Pakan dengan 20\% Pelepah Daun Kelapa Sawit Fermentasi

$\mathrm{P}_{2}=$ Pakan dengan 30\% Pelepah Daun Kelapa Sawit Fermentasi

Model linier yang digunakan untuk rancangan acak kelompok (RAK) adalah (Sastrosupadi, 2000) :

$$
\mathbf{Y}_{\mathrm{ij}}=\boldsymbol{\mu}+\mathbf{T}_{\mathbf{i}}+\mathbf{B}_{\mathbf{j}}+\sum_{\mathrm{ij}}
$$

Keterangan : $\mathrm{Y}_{\mathrm{ij}}=$ Nilai pengamatan dari perlakuan ke-i dan ulangan ke-j

$\mu \quad=$ Nilai tengah umum

$\mathrm{T}_{\mathrm{i}} \quad=$ Pengaruh perlakuan ke- $\mathrm{i}$

$\mathrm{B}_{\mathrm{j}} \quad=$ Pengaruh blok ke- $\mathrm{j}$

$\sum_{\mathrm{ij}}=$ Pengaruh galat dari perlakuan ke-i dan ulangan ke-j

\section{Parameter Penelitian:}

1. Konsumsi Pakan dalam Bahan Kering (BK) (kg)

Konsumsi pakan dihitung berdasarkan selisih antara jumlah pakan yang diberikan dikurangi dengan jumlah pakan yang sisa.

Konsumsi Pakan $=$ Pakan yang diberikan - Pakan sisa

2. Pertambahan Bobot Badan (g)

Pertambahan bobot badan diperoleh dengan menghitung selisih bobot badan akhir dengan selisih bobot badan awal. Dimana penimbangan dilakukan setiap 14 hari sekali.

Pertambahan Bobot Badan $=$ Bobot Badan Akhir - Bobot Badan Awal

3. Konversi Pakan

Konversi pakan merupakan ratio antara konsumsi pakan dengan pertambahan bobot badan.

$$
\text { konversi pakan }=\frac{\text { konsumsi pakan }}{\text { pertambahan bobot badan }}
$$

\section{HASIL DAN PEMBAHASAN}

Hasil penelitian pemanfaatan pelepah daun kelapa sawit fermentasi dengan A. niger dan limbah pabrik kelapa sawit pada performans sapi bali jantan selama masa penelitian tersaji dalam Tabel. 2. 
Tabel 2.Rekapitulasi hasil penelitian pemanfaatan pelepah daun kelapa sawit fermentasi dengan A. niger pada performans sapi bali jantan selama masa penelitian (kg/ekor/hari)

\begin{tabular}{cccc}
\hline Perlakuan & Konsumsi Pakan (BK) & $\begin{array}{c}\text { Pertambahan Bobot } \\
\text { Badan }\end{array}$ & Konversi Pakan \\
\hline P0 & $5,62 \pm 0,11^{\mathrm{a}}$ & $0,46 \pm 0,04^{\mathrm{a}}$ & $12,19 \pm 1,15^{\mathrm{b}}$ \\
P1 & $5,94 \pm 0,19^{\mathrm{b}}$ & $0,65 \pm 0,10^{\mathrm{b}}$ & $9,46 \pm 1,24^{\mathrm{a}}$ \\
P2 & $5,64 \pm 0,05^{\mathrm{a}}$ & $0,53 \pm 0,06^{\mathrm{ab}}$ & $10,25 \pm 1,30^{\mathrm{ab}}$ \\
\hline
\end{tabular}

Keterangan : notasi yang berbeda menunjukkan perbedaan yang nyata $(\mathrm{P}<0,05)$

Tabel 2 menunjukkan bahwa pemanfaatan pelepah daun kelapa sawit yang difermentasi oleh Aspergillus niger memberikan pengaruh berbeda nyata $(\mathrm{P}<0,05)$ terhadap konsumsi pakan, pertambahan bobot badan dan konversi pakan sapi bali jantan. Dapat dilihat perlakuan P1 (20\% pelepah daun sawit fermentasi) merupakan perlakuan yang paling baik pada konsumsi pakan, pertambahan bobot badan dan konversi pakannya dibanding dengan perlakuan lain. Hal tersebut juga menunjukkan bahwa sapi yang diberikan pakan dengan menggunakan pelepah daun kelapa sawit fermentasi lebih baik hasilnya dibandingan dengan sapi yang diberi pakan pelepah daun kelapa sawit segar tanpa fermentasi.

\section{Konsumsi Pakan dalam Bahan Kering (BK)}

Konsumsi pakan adalah kemampuan ternak dalam menghabiskan sejumlah pakan yang diberikan secara ad libitum. Konsumsi pakan dapat dihitung dengan pengurangan jumlah pakan yang diberikan dengan sisa pakan yang ada. Bahan kering adalah bahan yang terkandung di dalam pakan setelah diturunkan airnya.

Tabel 2 dapat dilihat bahwa rataan konsumsi tertinggi per perlakuan terdapat pada perlakuan P1 (20\% pelepah daun kelapa sawit fermentasi) sebesar 7,42 kg/ekor/hari dan rataan konsumsi terendah terdapat pada perlakuan P0 (25\% pelepah kelapa sawit segar).

Hasil yang didapatkan setelah dilakukan analisis sidik ragam pada data konsumsi pakan dalam bahan kering menunjukkan bahwa hasil penelitian berbeda nyata $(\mathrm{P}<0,05)$. Dapat dilihat terdapat perbedaan rataan jumlah konsumsi yang lebih besar pada pakan dengan pelepah daun kelapa sawit fermentasi dibandingkan dengan pakan yang mengunakan pelepah daun kelapa sawit segar (tanpa fermentasi). Pakan dengan pelepah daun kelapa sawit fermentasi memiliki nilai yang lebih besar dibanding dengan pakan dengan pelepah daun kelapa sawit segar. Hal ini bisa disebabkan karena pelepah daun kelapa sawit fermentasi memiliki kualitas pakan dan palatabilitas yang lebih baik dibandingkan dengan pelepah daun kelapa sawit segar. Hal ini sesuai dengan pernyataan Parakkasi (1995) bahwa tingkat perbedaan konsumsi dipengaruhi oleh beberapa faktor antara lain faktor ternak (bobot badan, 
umur, tingkat kecernaan pakan, kualitas pakan dan palatabilitas). Jumlah konsumsi bahan kering pakan dipengaruhi beberapa variabel meliputi palatabilitas, jumlah pakan yang tersedia dan komposisi kimia serta kualitas bahan pakan.

Konsumsi pakan antara lain dipengaruhi oleh bobot hidup ternak. Semakin tinggi bobot hidup ternak, konsumsi BK pakan semakin tinggi pula. Selain karena bobot hidupnya yang berbeda, konsumsi pakan yang berbeda ini juga dikarenakan bangsa ternak yang berbeda (Kearl, 1999). Menurut Tillman et.al., (1991) palatabilitas pakan dipengaruhi oleh beberapa faktor diantaranya rasa, bentuk dan bau dari pakan itu sendiri. Pakan konsentrat yang diberikan pada ternak masih dalam kondisi yang baik dan tidak ada efek ketengikan sehingga dapat meningkatkan konsumsi. Pemberian pakan konsentrat dapat meningkatkan daya cerna pakan secara keseluruhan, makin banyak konsentrat yang dapat dicerna, berarti arus pakan dalam saluran pencernaan menjadi lebih cepat, sehingga menyebabkan pengosongan rumen meningkat dan menimbulkan sensasi lapar pada ternak akibatnya memungkinkan ternak untuk menambah konsumsi pakan.

Menurut penelitian Situmorang (2010), rataan konsumsi tertinggi pada perlakuan pakan dengan menggunakan $15 \%$ pelepah dan daun kelapa sawit yang difermentasi Aspergillus niger yaitu sebesar 5790 g/ekor/hari. Data yang diperoleh dari penelitian tersebut tentu saja berbeda karena pada penelitian Situmorang pakan yang digunakan merupakan pakan konsentrat dengan penambahan pakan rumput/hijauan segar, sedangkan pada penelitian ini rataan tertinggi terdapat pada perlakuan pakan menggunakan $20 \%$ pelepah daun kelapa sawit fermentasi yaitu sebesar 7,42 kg/ekor/hari tanpa penambahan rumput/hijauan segar.

\section{Pertambahan Bobot Badan}

Pertambahan bobot badan sapi bali jantan dalam penelitian diperoleh dari hasil penimbangan bobot badan akhir dikurangi dengan bobot badan awal penimbangan. Penimbangan bobot badan dilakukan pada awal dan akhir periode. Rataan tertinggi terdapat pada perlakuan P1 (20\% pelepah daun kelapa sawit fermentasi) sebesar 0,65 kg/ekor/hari. Rataan secara keseluruhan sebesar $0,55 \mathrm{~kg} / \mathrm{ekor} / \mathrm{hari}$.

Hasil yang didapatkan setelah dilakukan analisis sidik ragam pada data pertambahan bobot badan sapi bali menunjukkan bahwa hasil penelitian berbeda nyata $(\mathrm{P}<0,05)$. Pertambahan bobot yang tinggi dapat terlihat pada perlakuan P1 (ransum dengan 20\% pelepah daun kelapa sawit fermentasi) yang menandakan pakan pada perlakuan tersebut 
mempunyai nilai nutrisi yang baik sehingga dapat memberikan respon yang baik terhadap pertumbuhan sapi bali dibanding dengan perlakuan lainnya. Dengan memberikan kombinasi pakan berupa ransum dengan $20 \%$ pelepah daun kelapa sawit fermentasi akan memberikan peluang terpenuhinya nutrisi yang dibutuhkan oleh sapi untuk petumbuhan dan perkembangan karena protein dapat diperoleh dari protein mikroba dan dapat digunakan sebagai sumber energi yang terdapat pada pakan penguat (konsentrat). Menurut Williamson and Payne (1993) konsentrat merupakan pakan tambahan yang diberikan untuk melengkapi kekurangan nutrisi yang didapat dari pakan utama yaitu hijauan. Konsentrat mempunyai kandungan energi, protein dan lemak yang relatif tinggi dengan kandungan serat kasar yang rendah dibanding hijauan yang diberikan.

Rataan pertambahan bobot badan pada penelitian sebelumnya oleh Situmorang (2010), yaitu data tertinggi pada perlakuan pakan dengan 30\% daun pelepah yang difermentasi oleh Aspergillus niger yaitu sebesar 515,48 g/ekor/hari. Data rataan pertambahan bobot badan yang diperoleh pada penelitian ini lebih tinggi yaitu sebesar 0,65 $\mathrm{kg} / \mathrm{ekor} / \mathrm{hari}$ yaitu pada perlakuan pakan $20 \%$ pelepah daun kelapa sawit fermentasi. Semakin tinggi konsumsi pakan maka akan semakin besar kemungkinan ternak untuk mengalami pertambahan bobot badan yang lebih besar. Namun ada kalanya hal ini tidak terjadi karena keadaan atau faktor- faktor lain, baik dari luar (lingkungan) maupun dari dalam ternak itu sendiri, misalnya pakan hijauan, genetik dan kondisi iklim.

Konsumsi pakan yang baik juga mempengaruhi pertambahan bobot badan pada sapi. Konsumsi pakan dengan kualitas pakan yang baik dapat mepercepat laju pertumbuhan dan meningkatkan produksi ternak. Hal ini sesuai dengan Tillman et.al.(1991), yang menyatakan bahwa kuantitas dan kualitas pakan yang diberikan menyangkut dengan tinggi rendahnya produksi dan kecepatan pertumbuhan sapi yang sedang tumbuh. Kualitas pakan erat hubungannya dengan pemilihan bahan-bahan pakan penguat.

\section{Konversi Pakan}

Konversi pakan merupakan ratio antara konsumsi pakan dengan pertambahan bobot badan. Rataan konversi tertinggi terdapat pada perlakuan P0 (ransum dengan 25\% pelepah daun kelapa sawit segar) yaitu sebesar 15,23 kg/ekor/hari sedangkan yang terendah terdapat pada perlakuan P1 (ransum dengan 20\% pelepah daun kelapa sawit fermentasi).

Hasil yang didapatkan setelah dilakukan analisis sidik ragam pada data konversi pakan menunjukkan bahwa hasil penelitian berbeda sangat nyata $(\mathrm{P}<0,01)$. 
Pertambahan bobot badan sapi bali jantan yang berbeda sangat nyata disebabkan oleh konsumsi pakan yang berbeda nyata, hal ini menghasilkan konversi pakan yang berbeda nyata juga. Konversi pakan yang berpengaruh sangat nyata juga disebabkan adanya pertambahan bobot badan dan konsumsi yang baik. Kualitas dan kuantitas pakan yang baik menghasilkan nilai konversi yang semakin kecil dengan kata lain pakan yang dikonsumsi minimal namun menghasilkan pertambahan bobot badan yang tinggi. Hal ini sesuai dengan pernyataan dari Hardianto (2000) yang menyatakan bahwa konversi pakan dipengaruhi oleh ketersediaan zat - zat gizi dalam ransum dan kesehatan ternak. Semakin tinggi nilai konversi pakan berarti pakan yang digunakan untuk menaikkan bobot badan persatuan berat semakin banyak atau efisiensi pakan rendah. Wahyuni dan Hardianto (2004) juga menyatakan bahwa konversi pakan dipengaruhi oleh ketersediaan zat - zat gizi dalam ransum dan kesehatan ternak, semakin tinggi nilai konversi pakan berarti pakan yang digunakan untuk menaikkan bobot badan persatuan berat semakin banyak atau efisiensi pakan rendah. Situmorang (2010) menyatakan bahwa angka konversi ransum dipengaruhi oleh strain dan faktor lingkungan didalamnya termasuk juga pakan. Konversi ransum ini juga untuk melihat seberapa besar pakan yang dikonsumsi bisa mempengaruhi kenaikan bobot badan sehingga pakan tersebut dikatakan baik. Menurut Lubis (1992) konversi pakan sangat dipengaruhi oleh kondisi ternak, daya cerna, jenis kelamin, bangsa, kualiltas dan kuantitas pakan, juga faktor lingkungan yang tidak kalah penting. Konversi pakan adalah perbandingan antara jumlah yang dikonsumsi pada waktu tertentu dengan produksi yang dihasilkan (pertambahan bobot badan) dalam kurun waktu yang sama. Konversi pakan adalah indikator teknis yang dapat menggambarkan tingkat efisiensi penggunaan pakan, semakin rendah angka konversi pakan berarti semakin efisien (Anggorodi, 1984).

Penelitian sebelumnya yang dilakukan oleh Situmorang (2010) diperoleh hasil rataan konversi pakan tertinggi terdapat pada perlakuan pakan dengan $15 \%$ pelepah daun kelapa sawit yang difermentasi Aspergillus niger yaitu sebesar 19,93, sedangkan rataan konversi pakan terendah terdapat pada perlakuan pakan dengan 30\% pelepah daun kelapa sawit yang difermentasi Aspergillus niger yaitu sebesar 11,32.

\section{KESIMPULAN}

Fermentasi pelepah daun kelapa sawit dengan menggunakan Asprgillus niger dapat meningkatkan konsumsi dan pertambahan bobot badan serta konversi pakan sapi bali dibandingkan dengan pelepah daun kelapa sawit segar. 


\section{DAFTAR PUSTAKA}

Anggorodi, R., 1984. Ilmu Makanan Ternak Umum. Gramedia, Jakarta.

Hardianto. R. 2000. Teknologi Complete Feed Sebagai Alternatif Pakan Ternak Ruminansia. Makalah BPTP Jawa Timur, Malang.

Kearl, L. C. 1999. Nutrient Requirement of Ruminant in Developing Countries. International Feedstuff Institute Utah Agriculture Experimants Station. Utah State University, Logan.

Lubis, D. A. 1992. Ilmu Makanan Ternak. PT. Pembangunan, Jakarta.

Parakkasi, A. 1995. Ilmu Nutrisi dan Makanan Ternak Ruminansia. UI Press, Jakarta.

Sastrosupadi, A., 2000. Rancangan Percobaan Praktis Bidang Pertanian. Kanisius, Jakarta.

Situmorang, P.T.G., 2010. Pemanfaatan Pelepah dan Daun Kelapa Sawit Fermentasi dengan Aspergillus niger terhadap Pertambahan Bobot Sapi Bali. Skripsi. Universitas Sumatera Utara, Medan.

Tillman, A. D., S. Reksohadiprodjo, S. Prawirokusumo, H. Hartadi dan S. Lebdosoekojo. 1991. Ilmu Makanan Ternak Dasar. Gadjah Mada University Press, Yogyakarta.

Umiyasih, U., Aryogi dan Y. N. Anggraeny. 2002. Pengaruh Jenis Suplementasi Terhadap Kinerja Sapi Peranakan Simental yang Mendapatkan Pakan Basal Jerami Padi Fermentasi. Prosiding Seminar Nasional Teknologi Peternakan dan Veteriner. Pusat Penelitian dan Pengembangan Peternakan. Departemen Pertanian, Bogor. Hal : 139 - 142.

Wahyono, D. E. dan R. Hardianto. 2004. Pemanfaatan Sumber Daya Pakan Lokal Untuk Pengembangan Usaha Sapi Potong. Jurnal Lokakarya Sapi Potong. Grati, Pasuruan.

Williamson and Payne. 1993. Pengantar Peternakan di Daerah Tropis. UGM-Press. Yogyakarta. 